\title{
Politik İklim Değişikliklerinin Ülkelerarası Ticaretle İlişkisi: Türkiye Rusya Uçak Krizi Üzerine Ekonometrik Bir İnceleme
}

\author{
Esin $\operatorname{Can}^{1}$ [0
}

\author{
Saniye Yıldırım Özmutlu ${ }^{2}$ (1)
}

\author{
Cansu Aykaç ${ }^{3}$ (])
}

Öz

Politik çevrenin temel bileşenleri; ideolojik iklim ve politik süreçler, milliyetçilik, yönetimlerin müdahaleleri ve politik istikrar olup, bu bileşenlerdeki değişimlerin ülkelerarası ticareti etkilemesi hem bilimsel hem de ülkeler ve işletmeler açısından kabul görmüş bir gerçektir. Bu gerçekten hareketle, çalışmanın amacı; 24 Kasım 2015 tarihinde Türkiye-Rusya Federasyonu arasında yaşanan uçak krizi sonrasında oluşan politik riskin iki ülke arasındaki dış ticaret hacmini nasıl etkilediğini ortaya koymak oluşturmaktadır. Böylece değişkenler arasında bağlant kurarak iki ülke arasındaki ticari ilişkilerin etkisi nicel bir çalışma üzerinde gösterilmiştir. Çalışma üç bölümden oluşmaktadır; illk bölümde politik risk kavramı, politik ve ticari ilişkiler kapsamı üzerinde durulmuştur. íkinci bölümde, bağımsız değişken olarak politik kriz, kontrol değişken olarak TÜFE bazlı reel efektif döviz kuru, TÜFE'nin aylık yüzdelik değişimi, Sanayi üretim endeksi, bağımlı değişken olarak Türkiye-Rusya dış ticaret hacmi ele alınmıştr. Ele alınan bu değişkenler kapsamında politik krizin, iki ülke arasında dış ticaret hacmi üzerine etkisi incelenmiştir. Çalışmada; politik riskin oluşması sonucunda Türkiye-Rusya Federasyonu arasındaki ticari ilişkilerin dış ticaret hacmi üzerindeki etkisini gösterebilmek amacıyla, STATA programı kullanılarak zaman serisi regresyon analizi yapılmıştır. Ayrıca Türkiye İstatistik Kurumu'ndan (TÜiK) ve Merkez Bankası'ndan (MB) alınan raporların sayısallaştıılması ile eldeki verilerin grafiklere yansıtılmasıyla dış ticaret hacmindeki değişim açıklanmaya çalışılmıştır. Yapılan analizler sonucunda politik krizin dış ticaret hacmi üzerinde negatif yönde ve anlamlı bir etkisinin olduğu sonucu elde edilmiştir. Başka deyişle; literatürde yer alan gerçek, somut bir olay üzerinde incelenerek ortaya konulmuştur. Çalışmanın son kısmında elde edilen sonuçlar değerlendirilmiş ve öneriler de bulunulmuştur.

\section{Anahtar Kelimeler}

Politik risk • Ticari ilişkiler • Türkiye-Rusya Federasyonu • Dış ticaret

The Effect of Changes in the Political Climate on Intercountry Trade: An Econometric Analysis on Turkey-Russia Aircraft Crisis

\section{Abstract}

The core components of the political environment are ideological climate and political processes, nationalism, interventions of governments and political stability. The effects of these changes on international trade are accepted reality in terms of scientific community, countries, and businesses. For this reason, the aim of this paper is to investigate the effect of the political crisis between Turkey and the Russian Federation after the airplane crises on November 24, 2015. Thus, the effect of commercial relations between the two countries by linking variables has been shown in a quantitative study. The study has three parts. In the first part, we look at the political risk concept and political and commercial relations. In the second part of the study, the political crisis is the independent variable and control variables are the CPI-based real effective exchange rate, the monthly percentage change in the CPI and industrial production index. The Turkey-Russia trade volume is considered as the dependent variable. We analyzed the effect of the political crisis on foreign trade volume within the scope of these variables. In order to show the effect of political relations on the foreign trade volume between Turkey and the Russian Federation, a time series regression analysis was conducted with the STATA program. In addition, changes in foreign trade volume were explained with charts obtained by digitization of the Turkey Statistics Institute (TUIK) and the Central Bank (MB) reports. As a result of these analyses, it is concluded that the political crisis has had a meaningful and a negative effect on foreign trade volume. In other words, the reality in the literature is examined by studying a concrete case. In the last part of the study, the results obtained were evaluated and recommendations were made.

\section{Keywords}

Political risk • Commercial relations • Turkey-Russian Federation • Foreign trade

1 Sorumlu Yazar: Esin Can (Prof. Dr.), Yıldız Teknik Üniversitesi, İktisadi ve İdari Bilimler Fakültesi, İşletme Bölümü, İstanbul, Türkiye. Eposta: eesincan@gmail.com ORCID: 0000-0003-1754-4867

2 Saniye Yıldırım Özmutlu (Öğretim Görevlisi), Namık Kemal Üniversitesi, Sosyal Bilimler Meslek Yüksekokulu, İşletme Bölümü, Tekirdağ, Türkiye. Eposta: saniyeyildirim58@gmail.com ORCID: 0000-0001-6199-3999

3 Cansu Aykaç (Doktora Öğrencisi), Yıldız Teknik Üniversitesi, Sosyal Bilimler Enstitüsü, İşletme Bölümü, İstanbul, Türkiye. Eposta: cansu.aykac@icloud.com ORCID: 0000-0002-7323-0611

Attf: Can, E., Yildirim Ozmutlu S., \& Aykac, C. (2019). Politik iklim değişikliklerinin ülkelerarası ticaretle ilişkisi: Türkiye Rusya uçak krizi üzerine ekonometrik bir inceleme. SiYASAL: Journal of Political Sciences, 28(1), 1-18. http://doi.org/10.26650/siyasal.2019.28.1.0001 


\section{Extended Summary}

Considering that there are nearly two hundred countries in the world today; the economic, socio-cultural and political situation of each state differs from one another. These differences occur according to the political and bureaucratic traditions of the countries, the nature of the political regime, the party or social groups that hold political power, the level of development of the countries, and the characteristics of the historical process in which they exist etc. For this reason, the aim of this paper is to investigate the effect of the political crisis between Turkey and Russian Federation after the airplane crises on November 24, 2015. When examined in the context of economic and political relations, Turkey downed the Russian Federation's plane on November 24, 2015 which added another strain to already turbulent Turkey and Russia relations. The crisis that took place on November 24, 2015 was the biggest crisis in the recent period.

The scope of this study is the reflection of political risk on commercial relations between Turkey and the Russian Federation. There is a comprehensive list of academic studies on business issues which have already been carried out such as Tourism relations, energy relations etc. However, the scope of this study - the effect of the aircraft crash on Turkey's import and export values - is not from an academic perspective. The study has three parts. In the first part, we look at the political risk concept and political and commercial relations. In the second part of the study, a time series regression analysis was conducted with the STATA program. In the last part of the study, the results obtained were evaluated and recommendations were made.

After Turkey downed the aircraft belonging to Russia on November 24, 2015, it faced a weakening of its strong trade relations with the Russian Federation. The aim of this study is to investigate the effect of trade relations between the two countries in terms of the volume of foreign trade as a result of political risk. The effect of commercial relations between the two countries by linking variables has been shown in a quantitative study. For this purpose, a time series regression analysis was performed in the STATA program. The data was constituted with the Turkey Statistics Institute (TUIK) and the Central Bank (MB) reports. The political crisis is the independent variable and the control variables are the CPI-based real effective exchange rate, the monthly percentage change in the CPI and industrial production index. The Turkey-Russia trade volume is considered as the dependent variable. We analyzed the effect of the political crisis on foreign trade volume within the scope of these variables. Monthly values of the data are used in the study and the time series covers the period from January 2005 to November 2017. The regression coefficient of the CRIS variable was negative (- 507). As mentioned in the literature, the political crisis between the two countries caused a decrease in the trade volumes of the countries. In this context, the hypothesis that political risk leads to disruption of international trade relations has been supported.

In addition to the regression analysis, changes in the volume of imports and exports are shown with the help of graphs. The results obtained from the regression analysis and the drawn graphics were supported and decreases in the volume of imports and exports are shown in the graphs. The lowest import volume with the Russian Federation was observed in the subsequent months after the aircraft crises covering Russia's sanctioning period. Traces of the political crisis created by the aircraft crisis were observed a year 
after the incident. In 2016, both import and export data were generally low. The levels of imports and exports seen in the data of 2015 could not be reached in 2017 but they paint a better picture than the levels in 2016.

In this study, Turkey's downing of an aircraft belonging to the Russian Federation and the implication of this event, consisting of political risk on commercial activities, was analyzed with time series regression and examined through two years of data shown in before and after graphs. As a result of the study, we can see that the political crises has had an effect on import and export volumes and also the severity of the crises has affected communication between the countries and the process of re-engaging in business activities. Economic relations between Turkey and Russia are sensitive to political events. It can be said that Turkey's strategies implemented after the crisis were not successful because Turkey's export data still has not reached that of 2014.

In conclusion, the political crises between the two countries have had a negative impact on the commercial activities of the countries. In order for political crises to have less negative impacts on the commercial activities of countries, it may be advisable to establish a partnership rather than a direct investment in countries with high political risks. 
Günümüzde Dünya üzerinde iki yüze yakın devlet bulunduğu düşünülürse; her bir devletin kendince ekonomik, sosyo-kültürel ve politik durumu birbirinden farklılık göstermektedir. Politik iklim, her ülkede farklı biçimlerde ve farklı tonlarda, kişi, kurum, firma ve devletlerin karşısına çıkmaktadır. Bu farklılıklar ülkelerin siyasal ve bürokratik geleneklerine, siyasal rejimin niteliğine, siyasal iktidarı elinde bulunduran parti ya da toplumsal gruplara, ülkelerin gelişmişlik düzeylerine, içinde bulundukları tarihsel sürecin özelliklerine vb. göre ortaya çıktığı bilinmektedir. Bu çalışmanın amacı işte bu noktadan hareketle; 24 Kasım 2015'de Türkiye'nin Rus uçağını düşürmesiyle ${ }^{3 *}$ yaşanan iki ülke arasındaki politik iklim değişikliğinin temel alınarak, politik riskin ülkelerarası ticarete yaptığı etkiyi belirlemektir. Bu süreçte ticari faaliyetlerdeki yansımayı sayısallaştırabilmek için Türkiye İstatistik Kurumu'ndan (TÜİK) ve Merkez Bankası'ndan(MB) alınan raporların grafiğe yansıtılması ve yorumlanması sonucunda ticari ve politik riskin oluştuğuna dair anlamlı verilere ulaşılması hedeflenmiştir. Çalışmada; Türkiye-Rusya arasında gerçekleşen uçak krizinin sonucunda, bir politik riskin oluşması ve bu riskin ithalat ve ihracat verileri üzerinde yaratmış olduğu etkiler analiz edilerek, politik iklim değişikliğinin ülkelerarası ticaret üzerine etkisi belirlenmeye çalışılmıştır.

Analiz için; 24 Kasım 2015 tarihinde Türkiye’nin bir Rus uçağını düşürmesi Türkiye’yi bir politik riskin eşiğine sürüklemiştir. Uçak krizinin yaşanmadan önceki ilk iki yıl (2013-2015) verileri ve uçak krizin yaşandığı yıl ve sonrasına (2015-2017) ait veriler Türkiye İstatistik Kurumunun (TÜIK) web sitesinden alınmıştır. Çalışmanın regresyon analizi kapsamında ki Ocak 2005- Kasım 2017 yılları arasındaki verilerin bazıları Merkez Bankası (MB) sitesinden alınmıştır. Çalışmada, Ocak 2005-Kasım 2017 yılları arasında zaman serisi analiz yöntemi kullanılmıştır.

\section{Literatür Araştırması}

\subsection{Politik Risk ve İlişkili Kavramlar}

Performansın bir varyantı olarak kullanılan risk kavramı, finans, ekonomi ve stratejik yönetimin içinde oldukça yaygın olarak kullanılmaktadır. Miller (1992) "Risk" kavramını önceden tahmin edilemeyen sonuçlar veya performanstaki değişiklikler olarak ifade etmiştir. Risk, organizasyonların iç veya dış faktörlere maruz kalması sonucunda oluşabilmektedir. $\mathrm{Bu}$ minvalde risk kavramı ile risk kaynakları ifade edilmektedir. Örneğin, "politik risk" ve "rekabetçi risk" kavramları ile riske sebep olan, risk kaynakları belirtilmektedir. Bu iki kavram, organizasyonların performansındaki öngörülemezliği, belirsiz çevresel bileşenlerle ilişkilendirilmektedir (Miller, 1992). Uluslararası yönetimde, risk hakkında yazılan makalelerin çoğunluğu "politik risk" kavramı üzerinde odaklanmıştır (Kobrin, 1982; Simon, 1984).

Literatürde politik risk, süreksizliğin bir sonucu olarak görülmektedir. Politik risk

3 "24 Kasım 2015 günü sabahı haber ajansları Suriye'de bir Rus uçağının düşürüldüğü bilgisini geçti. Akıllara gelen ilk soru uçağı kimin düşürdüğü oldu. Konuyla ilgili ilk resmi açıklama Genelkurmay Başkanlığı’ndan geldi.

Genelkurmay, "Türk Hava Sahasını ihlal eden milliyeti bilinmeyen bir uçak defalarca ikaz edilmesine rağmen Türk Hava Sahasını ihlal etmiştir. Söz konusu uçağa angajman kuralları çerçevesinde 24 Kasım 2015 saat 09.24 'te bölgede hava devriye görevinde bulunan iki adet F-16 uçağımız tarafından müdahalede bulunulmuştur." şeklinde açıklamada bulundu.

Genelkurmay açıklamasında 'Rus uçağı' ve 'düşürüldü' ifadelerini kullanılmazken, daha diplomatik bir dil tercih edildi. 'Rus uçağı düşürüldü’ ifadesi ilk kez Cumhurbaşkanlığı açıklamasında yer aldı. 
çevredeki ani değişimlere odaklanarak hükümet müdahalesi ve siyasi statüko değişiklikleri gibi farklı nitelikteki etkenler ile belirli bir olayın risk düzeyini tanımamaktadır. Politik risk birden fazla olayı kapsar ve dolayısıyla genişleyen bir siyasal risk kavramını temsil etmektedir. Fakat, ülkeler açısından politik risk değerlendirmesi temel olarak süreksizliklere odaklanmaktadır. Politik risk, ulusların ticaretini şekillendirerek riskin derecesini belirlemektedir (Fitzpatrick, 1983:249)

Truitt politik riski iş yapmama ya da işsizlik riski olarak tanımlamıştır (Truitt, 1974:12). Hofer ve Haller (1980), bütün politik risk tanımlamalarını kombine ederek bir model ortaya koymuştur ve ortaya çıkan modeli "politik risk uzun vadeli stratejik bir görünümü olan uzun bir süreç gerektirir" şeklinde tanımlamıştır (Fitzpatrick, 1983:252). Politik ilişkiler ülkeler arasında her zaman istikrarlı bir şekilde ilerlemez. Politik ilişkilerin ülkeler arasındaki bazı geçimsizliklerden dolayı düzensizleşmesi bir risk faktörünün doğuşunu tetiklemektedir. Politik riskin oluşması krizin varlığının habercisi olabilir.

Politik risk faktöründen bahsedebilmek için krizin kavramsal olarak anlamını bilmek gerekir. Kriz kavramı, gelecekteki tüm olayların trendinin daha iyi veya daha kötü olarak belirlendiği bir dizi olayı ifade etmektedir. Kriz bir hastalığın seyrinde, yaşamda, tarihte ve benzeri durumlardaki dönüm noktasıdır. Ayrıca zor zamanların, tehlikenin veya gelecek hakkında endişelerin görüldüğü zamandır (Hornby ve diğ., 1974: 206). Sosyal, ekonomik, politik veya uluslararası konular açısından belirleyici bir değişikliğe neden olan istikrarsızlık veya tehlike durumudur (Dictionary.com, 2017). Tüz'ün (1996) de bahsettiği gibi krizler birer karmaşadır ve bu karmaşada bazıları kaybeder, bazıları ise kazanırlar. Bu şekilde bir karmaşanın oluşması istikrarsızlığın varlığının göstergesidir. Politik istikrarsızlık; bir ülkenin içinde bulunduğu, toplumsal düzenin kontrolü ve korunması için gereken temel ön şartların süreli olarak kesintiye uğradığı ve dengesiz durumu nitelendirmektedir (Kesimli, 2011: 26). Türk-Rus ticari ilişkilerinde, Türkiye açısından geleneksel hale gelmiş bir dengesizlik söz konusudur (Özbay, 2011: 39). Özellikle uluslararası, çok uluslu veya global organizasyonların ana ülke veya ev sahibi ülkelerde çıkabilecek krizlere karşı hazırlıklı olmaları gerekmektedir.

Belirsizlikler iş faaliyetlerini etkileyen, istikrarsızlı̆̆ tetikleyen faktörlerdir. Belirsizliği ve istikrarsızlı̆ı̆ tetikleyen etmeleri farklı yazarlar çalışmalarında şu şekilde ele almıştır; Miller (1992) belirsizlikleri siyasi, hükümet politikaları, makroekonomik, sosyal ve doğal belirsizlikler olarak sıralamıştır (Miller, 1992). Daniell (2000) bu belirsizlikleri 4 boyutta değerlendirmiş ve finansal, kültürel, yasal ve politik riskler olarak sınıflandırmıştır. Hill (2002) ise çalışmasında Daniell'ın sınıflandırmasına benzer belirsizliklerden bahsetmiş fakat finansal riskleri dâhil etmemiştir.

Belirsizliği tetikleyen etmelerin başında siyasi, ekonomik, sosyal ve politik olaylar gelmektedir. Siyasi belirsizlikler genellikle politik rejimlerdeki büyük değişiklikleri içermektedir (Shubik, 1983; Ting, 1988). Miller'a (1992) göre politik sistemdeki potansiyel ve fiili değişiklerle ilişkili firsat ve tehditleri yansıtmaktadır. Bu belirsizliklerin kaynağı savaş, devrim veya siyasi kargaşalar olabilir. Yapılan bu çalışma, Miller'in (1992) yılında gerçekleştirmiş olduğu çalışmanın belirsizlik boyutlarından hareket ederek belirsizlik ve istikrarsızlığı tetikleyen etmelerin başında siyasi, ekonomik, sosyal, doğal ve özellikle politik olaylara yer verilmiştir. 
Devletin politikalarındaki belirsizlikler; iş çevrelerini etkileyebilir (Ting, 1988). Bazı yazarlar siyasi ve politikalardaki belirsizlikler için bir ayrım yapmamış ve bu iki kavram için "politik risk" terimini kullanmışlardır (Mustafaoğlu, 1978). Devlet politikalarındaki belirsizlik, mali ve para reformlarından, fiyat kontrolünden, ticari kısıtlamalardan, devlet kontrolünden, kamulaştırmadan ve kazanç geri dönüşündeki engellerden dolayı olabilmektedir (Miller, 1992).

Makroekonomik belirsizlikler; ekonomik faaliyet ve fiyatlar seviyesindeki dalgalanmaları kapsayan geniş bir kavramdır (Oxelheim ve Wihlborg, 1987). Fiyat dalgalanmaları, genel fiyat enflasyonu veya girdilerin (hammadde veya emek vb.) ve tüketim mallarının fiyatlarındaki hareketlenmeler şeklinde ifade edilebilir. Üretim ve fiyatlardaki hareketlilik ise genellikle faiz oranları ve döviz kurlarındaki hareketlilik ile ilişkilidir. Satın alma gücü paritesi, döviz kurlarındaki sapmalar, çok uluslu şirketler için girdi kaynağı ve ürün fiyatlandırma arbitraj firsatları yaratabilir (Miller, 1992).

Sosyal belirsizlikler; siyasi ve politik belirsizliğin habercisi olabilmektedir. Sosyal belirsizlikler toplumsal huzursuzluk, isyanlar veya küçük çaplı terörizm olaylarında ortaya çıkmaktadır. Eğer bu tür olaylar zamanla devlet için tehdit oluşturursa, politik istikrarsızlık ortaya çıkabilmektedir (Miller, 1992).

Doğal belirsizlikler, ekonomik çıktıyı etkileyen doğal fenomenleri içerir. Doğal belirsizlik, hava koşullarının verimliliği önemli ölçüde etkilediği tarım sektöründe en açık şekilde görülürler. Bunun yanı sıra, doğal felaketler (kasırgalar veya depremler vs.) sayısız iş fonksiyonuna zarar vererek üretim kapasitelerini önemli ölçüde düşürebilir (Miller, 1992).

\subsection{Türkiye-Rusya Federasyonu Arasındaki Politik ve Ticari İlişkiler}

1.2.1. Politik ilişkiler. Türkiye ile Rus Federasyonu arasındaki ilişkiler köklü bir mirasa dayanmaktadır. Beş yüzyıllık Türk-Rus ilişkilerinin tarihine bakıldığında barış ve iş birliğine dayanan dönemlerin istisnai aşamalar olduğu görülmektedir (Büyükakınc1, 2012: 779). Türkiye ve Rusya arasındaki ilişkilere bakıldığında istikrarlı bir ilerlemenin olmadığı iniş ve çıkışların yoğunlukta olduğu gözlemlenmektedir. Türk-Rus ilişkilerini 1990'lı ve 2000'li yıllar olarak ya da ekonomik ve politik ilişsiler bağlamında incelendiğinde, önemli dönemeçlerin yaşandığı tarihsel sürece bakarak üç farklı dönemde incelemek mümkündür. (Özbay, 2011: 37). Bu dönmelerde iki ülke arasındaki ilişkiler esas olarak "gergin" ve "mesafeli" olmuştur (Y1lmaz 2010: 28). Ekonomik ve politik ilişkiler bağlamında incelendiğinde 2015 yılında bu çalkantılı dönemlere bir dönem daha eklenerek Türkiye'nin Rus Federasyonu'na ait uçağı 24 Kasım 2015 tarihinde düşürmesi sonucu oluşan uçak krizi dönemi oluşturmaktadır.

Birinci dönem, 1992-1999 arasındaki ilk yıllardır. Bu dönemde her iki ülke de enerji, etnik, bölgesel gibi birçok alanda rekabeti öne çıkararak faktörler yeterince değerlendirememişlerdir. Bu yüzden politik anlamda birinci dönem Türk-Rus ilişkilerinin kayıp yıllarıdır.

Íkinci dönem, 2000-2008 arası yılları kapsar. Bu y1llar, her iki ülkenin yürüttükleri rekabetin ilişkiler bütününe verdiği zararı ve rekor düzeyde yükselen ekonomik ilişkilerin ortaya koyduğu faydayı göz önüne alarak, buradan çıkardıkları derslerle aralarındaki 
güven ilişkisini güçlendirme yönünde arayış içerisine girdikleri yıllardır. $\mathrm{Bu}$ yüzden politik anlamda ikinci dönem Türk-Rus ilişkilerinin arayış yıllarıdır diyebiliriz. 1990'lı yıllarda iki ülkenin ilişkilerinde ekonomik temelli gelişim ağırlıklıyken, politik ilişkilerin etkisi daha azdır. Fakat Türkiye'de 2002 yılının başlarında yaşanan siyasi güvensizliğin oluşması sosyal alanda krizin oluşmasına özellikle ekonomik krizin ağırlaşmasına neden olmuştur (Kantar, 2016: 675). 2002 yılının sonlarında iki ülke arasındaki siyasi ilişkilerin şekillenmeye başladığı yıllar olarak kabul edilebilir. 2002 yılında yapılan askeri iş birlikler, siyasi ilişkilerin gelişmesinde öncü olmuştur (Çopuroğlu ve Karpuzcu, 2017). 21. yy. da gelişen siyasi ilişkilerin etkisi özellikle 2004 yılında artarak, ekonomik ilişkiler kadar etkili olmuştur (Jazeera, 2016).

Üçüncü dönemi, 2008 sonrası yıllar olarak değerlendirebiliriz. Bu dönemde iki ülke ilişkilerinde kayıp yılların arkada kaldığı ve arayışın bittiği işbirliği yılları olma potansiyeli taşımaktadır (Özbay, 2011: 38-39). Dördüncü dönemi, 2015 yılı ve sonrası olarak değerlendirebiliriz.

Çalışmaya konu olan, 24 Kasım 2015 tarihinde yaşanan kriz yakın dönem içerisinde yaşanmış en büyük krizdir. Türkiye hava sahasını ihlal eden ve uyarılara rağmen devam ettiğini belirttiği SU-24 tipi Rus jetini Suriye sınırı yakınlarında düşürmüştür. Hali hazırda gergin olan Türk-Rus ilişkileri, yaşanan olay sonrasında kopma noktasına gelmiştir ve NATO’nun üyesi olan bir devlet ilk defa Rus uçağını düşürmüştür (Özlük, 2015: 2). Türkiye olay sonrasında hava sahasının ihlal edildiğini ve angajman kurallarının gerekli uyarılardan sonra uçağı düşürdüğünü açıklamıştır. Rusya ise olay sonrası "sırtımızdan bıçaklandık" şeklinde açıklamada bulunmuştur. Ayrıca, Türkiye uçağın milliyetini bilmediğini eğer Rus uçağı olduğunu bilseydi tutumunun farklı olacağını belirtmiştir (BBC, 2015a). Rusya ise "Türkiye'nin uçağın milliyetini bilmeme ihtimalinin olmadığı" yanıtını vermiştir (Zete, 2015). Yaşanan olay sonrasında Rusya Türkiye'den özür beklerken uygulayacağ1 yaptırımları açıklamıştır. Rusya'nın beklediği özür üzerine Türkiye yaptıklarının meşru bir hak olduğunu belirmiştir ve tazminat talebini reddetmiştir. Fakat daha sonra Türkiye diplomatik bir mektup ile Rusya'dan özür dilemiştir (BBC, 2016b).

Uçak Krizi Türk-Rus ilişkileri açısından önemli bir dönüm noktası olmuştur. Sürekli çatışmacı bir seyir izleyen Türk-Rus ilişkileri 2000'li yılların başından beri gerçekleşen tarihi yakınlaşmanın kırılma anlarından biri olmuştur. Böylece Türk-Rus İlişkileri olağan seyrine dönmeye başlamıştır (Bilgin ve Çelik, 2016). 2015 yılı sonları itibariyle yaşanan Uçak Krizi Türkiye-Rusya Federasyonu ilişkilerinin yeniden ele alınması gerektiğini ortaya koymuştur (Zengin, 2015: 63).

Kısacası, uçak krizi öncesindeki son dönem Türk-Rus ticari ilişkilerinde iyi geçen son dönemdir. Bundan önceki iki dönemde ekonomik ilişkiler daha ön plandayken daha sonra politik ilişkilerin önemi artmıştır. Politik ilişkilerdeki artan dinamizm temelinde ise ekonomik ilişkiler yer almaktadır. Üçüncü dönemde ise politik ve ekonomik ilişkilerin her ikisi de gücünü bir diğerinden almaktadır (Çopuroğlu ve Karpuzcu, 2017). Türk-Rus ilişkilerindeki yakınlaşmalar incelendiğinde genellikle bölgesel ve küresel dengelerin bozulmasının ardından gerçekleştiği gözlemlenmektedir. İki devletin, ilişkilerinin iyileştiği dönemler bölgelerindeki güvenlik riskinin arttığı ve küresel dengelerin değiştiği zamanlardır. Yani, bölgelerinde üçüncü bir gücün etkin olması durumundan, iki ülkenin ittifakı oluşmaktadır (Çopuroğlu ve Karpuzcu, 2017). 
1.2.2. Ticari ilişkiler. İki ülke arasındaki enerji ilişkileri, 1984'te imzalanan doğal gaz anlaşması ile başlamıştır. 1997 yılında imzalanan Mavi Akım Anlaşması’nın Karadeniz'den geçirmeyi planladığ 1 doğal gaz boru hattı 2005 yılında hayata geçmiş olup, "Mavi Akım Anlaşması" enerji alanında iki ülke arasında "Bakü-Tiflis-Ceyhan" petrol boru hattı konusunda yaşanan rekabetin yerine işbirliği yaklaşımının ortaya konulması açısından çok önemli olmuştur. Mavi Akım bir anlamda daha sonraki yıllarda gittikçe artacak olan ikili ilişkilerin itici gücü olmuştur. Mavi Akım'ın hayata geçmesiyle Türkiye, Rusya'nın enerji alanındaki en büyük ortaklarından biri haline gelmiştir (Özbay, 2011: 41). 2000'li yıllarda başlayan enerji ithalatından dolayı, Türkiye'nin en çok ithalat yaptığı ülkeler arasında Rusya ilk sırada yer almıştır. Bu sebepten dolayı Türkiye ve Rusya arasındaki ticari ilişkiler her iki ülke içinde önem arz etmektedir (Akbulut ve Y1lmaz, 2015).

İki ülke arasındaki ticaret incelendiğinde, Türkiye'nin kahve, çay, kakao, baharat ve ürünleri, seyahat eşyası, el çantaları vb. taşıyıcı eşya, ayakkabılar ve aksamı, meyve ve sebzeler, giyim eşyası ve bunların aksesuarları, motorlu kara taşıtları, bisiklet ver motosikletler, bunların aksam ve parçası, hayvansal ve bitkisel gübreler, tuz, kükürt, topak, alçı gibi mineral maddeler, prefabrik yapılar, sıhhi su tesisatı, 1sıtma ve sabit aydınlatma cihazları, tekstil ürünleri, güç üreten makineler ve araçlar, balıklar ve diğer deniz ürünleri, tıp ve eczacılık ürünleri, mobilya, yatak takımı, yatak payandaları ve yastıklar, elektrik makineleri, cihazları ve aletleri, vb. aksam parçaları ürünlerinde; Rusya Federasyonu'nun ise petrol gazları, doğal gaz ve diğer mamul gazlar, taş kömürü, kok kömürü ve briket kömürü, hayvanlar için gıda maddeleri, mineral kimyasal gübreler, hububat, hububat ürünleri, bitkisel sıvı yağlar ve fraksiyonları, demir ihtiva etmeyen madenler, petrol, petrolden elde edilen ürünlerde karşılaştırmalı olarak üstün olduğu görülmektedir (Kalayc1, 2013: 56-59).

\subsection{Politik Risk Sonrasında Rusya Federasyonu'nun Türkiye'ye Olan Yaklaşımı}

Ticari anlamda Türkiye'nin en büyük ortaklarından Rusya ile 24 Kasım 2015 tarihinde meydana gelen kriz sonrasında, iki ülke arasında ekonomik anlamda gerginlikler meydana gelmiştir. Kriz sonrası, Rusya Federasyonu Türkiye ile ilişkilerinde ekonomik yaptırımlar uygulama kararı almıştır. Bu ekonomik yaptırımları şu şekilde sıralanabilir (Demir, 2015: $1)$;

$\checkmark \quad$ Türkiye'den ithal edilen gıda ürünlerinin ithalatının durdurulması,

$\checkmark$ Türkiye'ye tatil paketi satan turizm şirketlerini uyararak, satışların durdurulması,

$\checkmark$ Türkiye' den yapılan charter uçuşların durdurulması,

$\checkmark \quad$ Serbest vize sürecinin askıya alınması ve

$\checkmark$ Rusya' da çalışan Türklerin işe alınmalarında kısıtlamalara gidilmesi.

Rusya'nın ekonomik anlamda önemli bir ticari ortağı olan Türkiye'ye uygulamış olduğu yaptırımların iyi hesaplanmış politikanın sonucu olarak görülebilir. Çünkü Rusya'nın Türkiye ile çok yönlü ekonomik ilişkileri oldukça önemlidir. Türkiye'nin ithalat ve ihracat dengesi açısından stratejik bir öneme sahip olan Rusya, bu yaptırımlar ile Türkiye'nin ekonomik anlamda kayıplar yaşayacağını düşünerek bu yaptırımları uygulamıştır (Bilgin ve Çelik, 2016). Türkiye-Rusya Federasyonu arasında 2000'li yıllar 
ve sonrasında ara ara iş birliğinin olduğu ama daha çok çalkantılı bir politik istikrarsızlığın yaşandığı dönemleri kapsamaktadır. 24 Kasım 2015 yılı uçak krizi ile oluşan bir politik riskin ticaret olguları üzerindeki volkanik patlamanın yaşandığı ve özellikle Türkiye açısından istikrarsızlığın baş gösterdiği bir sürece dönüşmüştür.

Yapılan araştırmada, 24 Kasım 2015 tarihinde Türkiye tarafından bir Rus uçağının düşürülmesi ve bu olayın uçak krizi olarak adlandırılması, Türkiye-Rus Federasyonu arasında bir politik krizin yaşanmasına sebebiyet vermiştir. Yapılan bu çalışmada yaşanan bu politik krizin ticareti nasıl etkilediği incelenmiştir.

\subsection{Türkiye-Rusya Federasyonu İle İlgili Daha Önce Yapılan Çalıșmalar}

Yapılan araştırmalar sonucunda Türkiye-Rusya Federasyonu arasındaki ilişkileri turizm, doğal gaz, enerji gönderimi ve genel olarak iki ülkenin ilişkilerinin boyutları açısından inceleyen çalışmalar mevcuttur. Bilgin ve Çelik (2016) "Uçak Krizinin Türkiye Ekonomisi Üzerindeki Etkisinin Diş Ticaret Verileriyle Değerlendirilmesi” isimli çalışmalarında Türkiye ve Rusya arasındaki ithalat ve ihracat verilerini 2005 ve 2016 y1llarındaki seyrini incelemiş ve özellikle turizm, inşaat, hammadde ve gıda sektörleri üzerindeki etkilerine bakmışlardır. Demir ve Çınar (2016) ise uçak krizinin etkilerini incelemek için 2015 tarihine kadar ki dış ticaret verilerini ele alarak açıklamışlardır. Bazı çalışmalar ise krizlerle dolu Türk-Rus ticari ilişkilerine basın da yer alan haberleri inceleyerek, öngörülerde bulunmuşlardır (Çopuroğlu ve Karpuzcu, 2017). Politik krizlerin etkisini araştıran birçok çalışma yaşanan olayın etkilerini turizm sektöründe yaşanan sıkıntılar üzerinden ele almıştır (Kesimli, 2011; Yenişehirlioğlu ve diğ., 2016). Babali (2012), yapmış olduğu çalışmada, Türkiye'nin Rusya ve İran'dan enerji alımında uygulamış olduğu stratejilerin neler olduğu ve enerji alımında güvenliği sağlamak için nasıl bir yol izlediği açıklamıştır. Bourgeot (2013) ele aldığg çalışmada, Rusya ve Türkiye arasında ekonomik ve güç dengesini sağlamanın zor olduğu ve ekonomik ilişkilerin özellikle enerji çıkarlarına dayandığını açıklanmıştır. Çalışma; bu güne kadar yapılanların ele aldığı konu bağlamında farklılık göstermesi ve diğer çalışmaların değinmediği farklı zaman aralıklarını dikkatte alarak, yaşanan uçak krizinin etkilerini belirli bir sektör açısından bakmak yerine genel bir bakış açısıyla irdelenmesi açısından özgündür. $\mathrm{Bu}$ bağlamda, öncelikle Ocak 2005-Kasım 2017 yılları arasında politik riskin ticari faaliyetler açısından etkisi zaman serisi regresyon analizi ile açıklanmıştır. Zaman serisi regresyon analizi yapıldıktan sonra, Türkiye-Rusya arasında uçak krizinin yaşanmadan önceki 2 y1llık ve kriz sonrasında yaşanan 2 yıllık süreçteki ithalat ve ihracat verileri incelenerek politik krizlerin etkileri ilk kez bu çalışmada incelenerek diğer çalışmalardan farklılığı ortaya çıkarılmaktadır.

\section{Metodoloji}

\subsection{Araştırmanın Kapsamı ve Hipotezi}

Çalışmanın kapsamını, Türkiye ile Rusya Federasyonu arasındaki politik riskin ticari ilişkilerdeki yansımasının nasıl olduğunun belirlenmesi oluşturmaktadır. Türkiye ve Rusya Federasyonu arasındaki iş konusunda, turizm ilişkileri, enerji ilişkileri vb. çok kapsamlı akademik çalışmalar yapılmasına rağmen özellikle 24 Kasım 2015 tarihinde Türkiye'nin Rusya Federasyonu'na ait bir uçağı düşürmesi sonrasında ithalat ve ihracat 
değerlerinde nasıl bir değişimin oluştuğu kapsamında bir çalışmaya rastlanılmamıştır. Bu bağlamda araştırmanın amacını; 24 Kasım 2015 tarihinde Türkiye ve Rusya Federasyonu arasında yaşanan uçak krizi sonrasında politik bir risk oluşturması ve iki ülke arasındaki ticaretin TÜİK ithalat ve ihracat verilerine bakarak ortaya konulması oluşturmaktadır.

Türkiye ve Rusya Federasyonu arasında yaşanan uçak krizi sonrasında oluşan politik riskin, reel döviz kur, TÜFE ve sanayi üretim endeksin iki ülke arasındaki dış ticaret hacmini nasıl etkilediğine yönelik Şekil 1'de gösterilen model üzerinden çalış1lmıştır. Oluşturulan bu model bağlamında amaca uygun olarak araştırmanın hipotezi oluşturulmuştur.

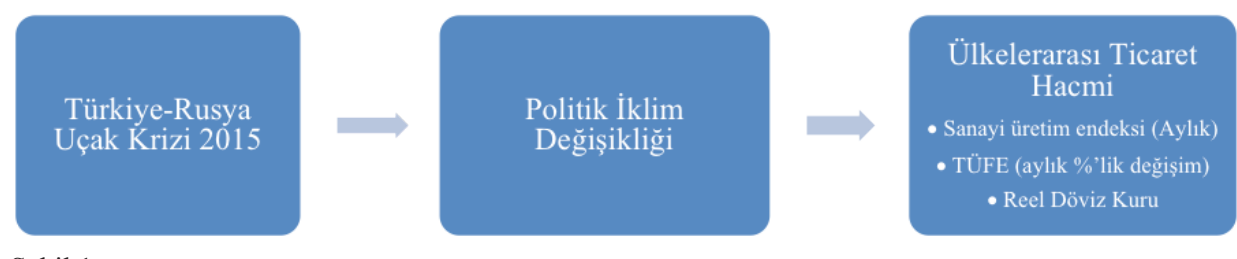

Şekil 1

Araştırma modeli

$H_{l}$ : Politik iklim değişikliği ülkelerarası ticareti olumsuz etkiler.

\subsection{Araştırma Metodolojisi ve Ölçme}

Türkiye'nin 24 Kasım 2015 tarihinde Rusya Federasyonuna ait uçağı düşürmesi ve oluşan politik risk faktörü sonrasında Türkiye-Rusya Federasyonu ile güçlü ticari ilişkilerin zayıflaması durumu ile karşılaşmıştır. Çalışmanın yapılmasının amacı, politik riskin oluşması sonucunda iki ülke arasındaki ticari ilişkilerin dış ticaret hacmi üzerindeki etkisini araştırmak oluşturmaktadır. Bu amaçla STATA programında zaman serisi regresyon analizi yapılmıştır. Bağımsız değişken olarak politik kriz, kontrol değişken olarak TÜFE bazlı reel efektif döviz kuru, Sanayi üretim endeksi ve TÜFE'nin aylık yüzdelik değişimi ve bağımlı değişken olarak Türkiye-Rusya dış ticaret hacmi ele alınmıştır. Bu çalışma da, Kasım 2015 tarihinde yaşanan politik krizin Türkiye-Rusya arasındaki dış ticaret üzerindeki etkisini göstermek amaçlanmaktadır. Verilerin aylık değerleri kullanılmış olup, zaman serisi Ocak 2005- Kasım 2017 yıllarını kapsamaktadır.

Çalışmada bağımsız değişken olan politik iklimin değişmesinin yol açtığı "Politik kriz" değişkeni (değişken adı: KRİZ) kukla (dummy) değişken olup, Ocak 2005- Kasım 2015 tarihi arasına "0" , kriz sonrası dönem (Aralık 2015-Kasım 2017) ise "1" ile kodlanmıştır. TÜFE bazlı reel efektif döviz kuru enflasyondaki farkları dikkate alarak hesaplanmaktadır ve ülke ekonomisi hakkında daha fazla bilgiyi kapsamaktadır. Ayrıca ülkenin dış rekabet gücünün bir göstergesi olarak kullanıldığından (Savaş ve Can, 2011), bu çalışmada döviz kuru (yabancı bir paranın milli para birimi cinsinden değeri) yerine "TÜFE bazlı reel efektif döviz kuru” (değişken adı: KUR) kullanılmıştır. Gayri safi yurt içi hasılanın (GSYİH) çeyrek dönemlik veriler olmasından dolayı, aylık bazda seriler içerdiğinden sanayi üretim endeksi (değişken adı: SUE) kullanılmıştır. TÜFE'yi doğrudan kullanarak seride durağanlık oluşturmamak için TÜFE'nin aylık yüzde değişimleri (değişken adı: TÜFE\%) kullanılmıştır. Sanayi üretim endeksi, TÜFE'nin aylık yüzdelik değişimi ve Türkiye-Rusya dış ticaret hacmi zaman serilerine Türkiye İstatistik Kurumunun (TÜİK) web sitesinden alınıştır. TÜFE bazlı reel efektif döviz kuru veri seti ise Türkiye Cumhuriyeti Merkez Bankası'nın (TCMB) istatistik veri tabanından 
ulaşılmıştır. Literatürde, 2000 yılından sonra Türkiye-Rusya arasında yükselen ekonomik ilişkiler olduğu belirtilmiştir. Fakat "SUE" değişkeni için 2005 y1lı öncesi veriler bulunmadığından veri seti 2005 ve 2017 yıllarını kapsamaktadır.

2.2.1. Türkiye'nin 2013-2017 yılları arasında TÜİK raporunda yer alan ülkeler ve Rusya Federasyonu arasındaki ithalat-ihracat verileri. Regresyon analizinde politik krizin dış ticaret hacmi üzerinde negatif ve anlamlı ilişkisi bulunmuştur. Yani, politik kriz var oluğunda diş ticaret hacmi düşmektedir. Çizilen grafikler ile regresyon analizinden elde edilen sonuçlar birbirlerini desteklenmiş ve ithalat ve ihracat hacmindeki düşüşler gösterilmiştir.

Şekil-2, 2013-2017 yılları arasında Türkiye'nin TÜİK raporunda yer alan ülkeler arasındaki ithalat ve ihracat verileri ile Türkiye-Rusya Federasyonu arasındaki ithalat ve ihracat verilerini göstermektedir.

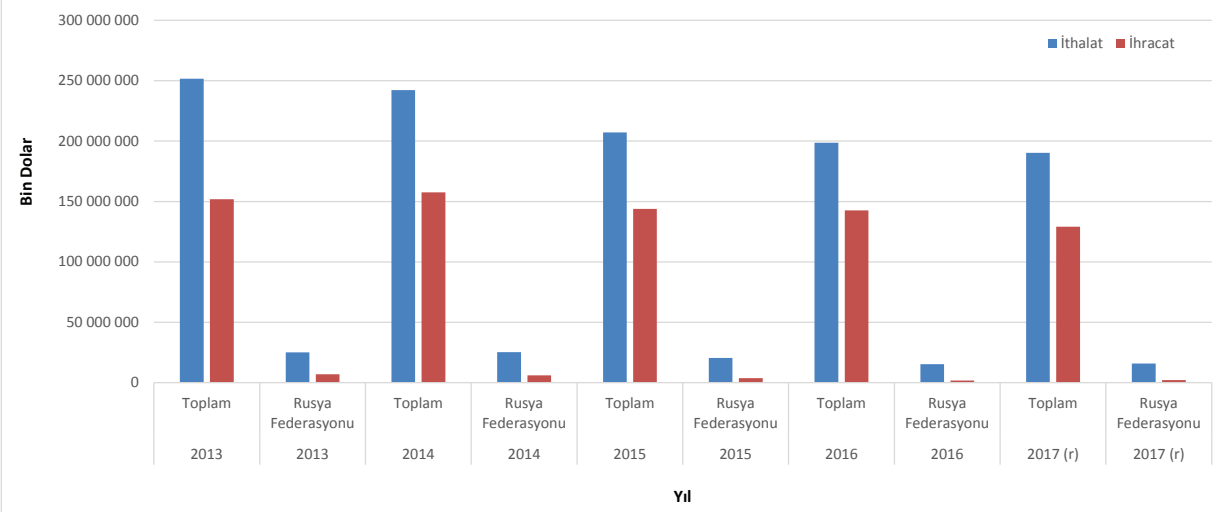

Şekil 2

Türkiye'nin toplam ithalat ihracat hacmi ve Rusya Federasyonu verileri

Şekil-3 2013-2017 yılları arasında Türkiye-Rusya Federasyonu arasındaki ithalat ve ihracat verilerini sayısal olarak daha net görebilmemize ve anlamlandırabilmemize olanak sağlamaktadır.

TÜİK raporundaki verilerin işlenmesi ve elde edilen bilgiler doğrultusunda 2013 yılında Türkiye'nin TÜİK raporunda yer alan tüm ülkelere yapmış olduğu ithalatı 252 milyar dolar, ihracatı ise 152 milyar dolardır. 2013 yılında Türkiye'nin Rusya Federasyonu'na yapmış olduğu ithalatı 25 milyar dolar, ihracatı ise 7 milyar dolardır. 2013 yılı değerleri sonuçlarına göre, Türkiye Rusya Federasyonu'ndan yaklaşık 3,6 kat daha fazla mal ve hizmet satın almıştır. 


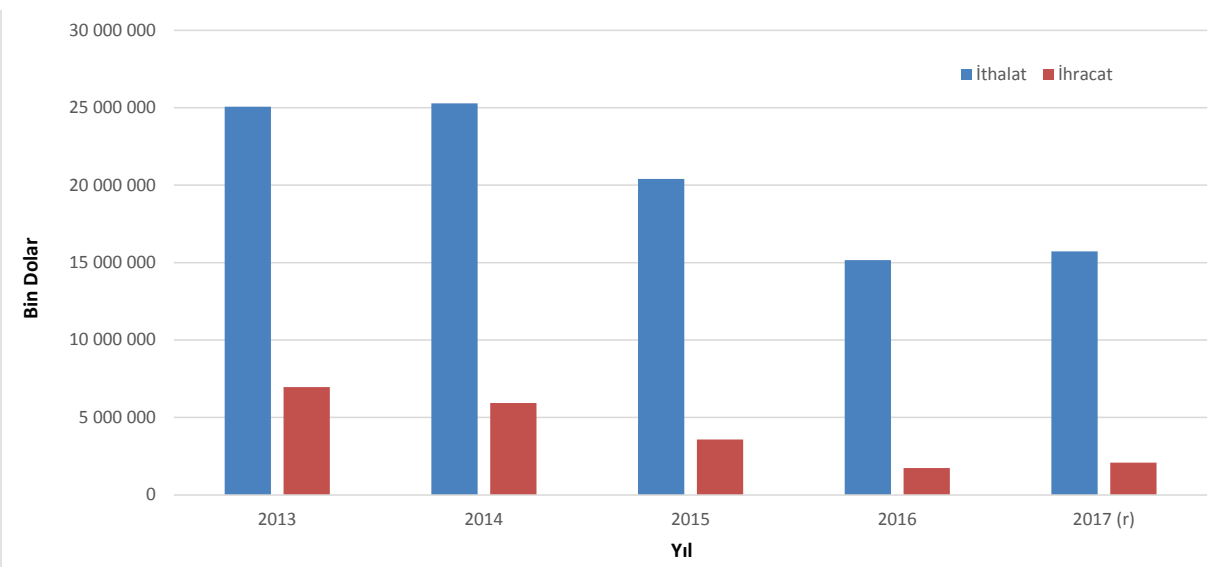

Şekil 3

Türkiye - Rusya Federasyonu arasindaki ithalat ihracat verileri

2014 yılında Türkiye'nin TÜiK raporunda yer alan tüm ülkelere yapmış olduğu ithalatı 242 milyar dolar, ihracatı ise 158 milyar dolardır. 2014 yılında Türkiye'nin Rusya Federasyonu'na yapmış olduğu ithalatı 25 milyar dolar, ihracatı ise yaklaşık 6 milyar dolardır. 2013 yılına göre Türkiye'nin Rusya Federasyonu'na yapmış olduğu ihracat kaybı 1 milyar dolardır. 2014 yılı değerleri sonuçlarına göre, Türkiye Rusya Federasyonu'ndan yaklaşık 4,16 kat daha fazla mal ve hizmet satın almıştır.

2015 yılında Türkiye'nin TÜİK raporunda yer alan tüm ülkelere yapmış olduğu ithalatı 207 milyar dolar, ihracatı ise yaklaşık 144 milyar dolardır. 2015 yılında Türkiye'nin Rusya Federasyonu'na yapmış olduğu ithalatı 20 milyar dolar, ihracatı ise yaklaşık 3,6 milyar dolardır. 2014 yılına göre Türkiye'nin Rusya Federasyonu'na yapmış olduğu ithalat kaybı 5 milyar dolar ve ihracat kaybı 2,4 milyar dolardır. Kasım ayı uçak kriz sonrası Rusya'nın uygulamış olduğu yaptırımlar, Türkiye'nin aleyhine olacak şekilde ciddi anlamda daralmaya başlamıştır. 2015 yılı değerleri sonuçlarına göre, Türkiye Rusya Federasyonu'ndan yaklaşı 5,55 kat daha fazla mal ve hizmet satın almıştır. 2015 yılı verileri değerlendirmesi sonucunda, hem ithalat hem ihracat verilerinde azalma söz konusudur. Türkiye Rusya Federasyonundan daha çok enerji ürünleri satın aldığı için bu durumdan daha çok etkilenen taraf olabilir.

2016 yllında Türkiye'nin TÜIKK raporunda yer alan tüm ülkelere yapmış olduğu ithalatı yaklaşı 197 milyar dolar, ihracatı ise yaklaşık 143 milyar dolardır. 2016 yılında Türkiye'nin Rusya Federasyonu'na yapmış olduğu ithalatı 15 milyar dolar, ihracatı ise yaklaşık 1,7 milyar dolardır. Bir önceki yıla göre, Türkiye'nin Rusya Federasyonu'na yapmış olduğu ihracatı yarıdan daha fazla 1,9 milyar dolar azalmıştır. 2016 yılı değerleri sonuçlarına göre, Türkiye Rusya Federasyonu'ndan yaklaşık 8,82 kat daha fazla mal ve hizmet satın almıştır. 2016 yılı verileri değerlendirilmesi sonucunda hem ithalat hem ihracat verilerinde ciddi azalma söz konusudur. 2015 yılı kasım ayından sonra uçak krizinin iki ülke arasında yaratmış olduğu politik risk, Rusya Federasyonu'nun Türkiye üzerindeki ithalat ve ihracat üzerindeki yaptırımı Türkiye'nin aleyhine işleyecek düzeyde düşüş göstermiş olarak görülmektedir. 2015 yllına göre Türkiye'nin Rusya Federasyonu'na yapmış olduğu ithalat kaybı 5 milyar dolar ve ihracat kaybı ise 1,9 milyar 
doları bulmuştur.

2017 y1lında Türkiye'nin TÜİK raporunda yer alan tüm ülkelere yapmış olduğu ithalatı yaklaşık 190 milyar dolar, ihracatı ise yaklaşık 129 milyar dolardır. 2017 yılında Türkiye'nin Rusya Federasyonu'na yapmış olduğu ithalatı yaklaşı 16 milyar dolar, ihracatı ise yaklaşık 2,1 milyar dolardır. 2017 yılı değerleri sonuçlarına göre, Türkiye Rusya Federasyonu'ndan yaklaşık 8,57 kat daha fazla mal ve hizmet satın almıştır. 2017 yılı Ekim ayı verilerine kadar yapılan değerlendirmelerde, Türkiye'nin Rusya Federasyonu'na yapmış olduğu ithalatı bir önceki yıla göre 1 milyar dolar artmış ve ihracatı da 0,4 milyar dolarlık varla yok arasında bir artışın gözlemlenmesi ile sonuçlanmıştır.

Türkiye-Rusya Federasyonu arasındaki ihracatımızda yaşanan daralmaların kaynağı çok çeşitlidir. Bu daralmanın en büyük nedenleri arasında Rusya'nın Türkiye'ye olan turizm faaliyetlerini durdurması ve çeşitli gıda mallarının ihracatının Rusya tarafından durdurulmasıdır. Türkiye Cumhuriyeti Dışişleri Bakanlığının 2016'da yaptığı açıklamada 2016 yılının ilk 2 ayının bir önceki senenin aynı dönemi ile karşıllaştırıldığında ihracat $\% 61,5$ azalırken, ithalatın ise \%32,8 gerilediği belirtilmiştir (Türkiye Cumhuriyeti Dişişleri Bakanlığı, 2016).

2.2.2. Regresyon analizi. Yapılan regresyon analizi Kasım 2015 tarihinde yaşanan politik krizin ithalat ve ihracat üzerindeki etkisini incelemeye yöneliktir. Bağımlı değişken Türkiye-Rusya arasındaki dış ticaret hacmidir (Değişken adı: HACIM). Bağımsız değişken ise kukla değişkenimiz olan politik kriz (KRİZ) ve kontrol değişkenler olarak TÜFE bazlı reel efektif döviz kuru (KUR), Sanayi üretim endeksi (SUE) ve TÜFE'nin aylık yüzdelik değişimi (TÜFE\%) kullanılmıştır. Çalışmada KRIZZ değişkenin katsayısının negatif olması beklenmektedir. Başka bir deyişle kriz olduğunda dış ticaret hacminin düşmesi beklenmektedir.

Veri setinde durağanlığı incelemek için Dicky-Fuller (DF) testi yapılmıştır. Tablo 1 'de gösterilen ADF testinin sonuçlarına göre modelde kullanılan TÜFE\%, HACİM ve SUE değişkenleri durağandırlar. Fakat KUR düzeyde durağan değildir. Bu nedenle KUR değişkeninin birinci farkı alınarak durağan hale getirilmiştir.

Tablo 1

ADF birim kök testi sonuçlarl

\begin{tabular}{|l|l|l|l|l|}
\hline \multirow{2}{*}{ Düzey } & DF Test Değeri & \multicolumn{4}{|l|}{ ADF Kritik Değerleri } & $\mathbf{5 \%}$ & $\mathbf{1 0 \%}$ \\
\cline { 2 - 5 } & & $\mathbf{1 \%}$ & -2.886 & -2.576 \\
\hline TÜFE\% & -10.285 & -3.492 & -2.886 & -2.576 \\
\hline HACİM & -3.268 & -3.492 & -2.886 & -2.576 \\
\hline SUE & -3.543 & -3.492 & -2.886 & -2.576 \\
\hline KUR & -1.091 & -3.492 & $\mathbf{2}$ \\
\hline \multirow{2}{*}{ Birinci Fark } & DF Test Değeri & ADF Kritik Değerleri & $\mathbf{1 0 \%}$ \\
\cline { 2 - 5 } & & $\mathbf{1 \%}$ & $\mathbf{5 \%}$ & -2.576 \\
\hline \multirow{2}{*}{ dlKUR } & -9.873 & -3.492 & -2.886 & \\
\hline
\end{tabular}

Tanımlanan regresyon denklemi aşağıdaki gibidir:

$\mathrm{HACIM}=\beta 0+\beta 1(\mathrm{SUE})+\beta 2(\mathrm{TÜFE} \%)+\beta 3(\mathrm{KRIZ})+\beta 4 \log (\mathrm{KUR})+u i$

Regresyon sonuçları Tablo 2'de gösterilmiştir. 
Tablo 2

Regresyon analizi sonuçları

\begin{tabular}{|c|c|c|c|c|}
\hline \multicolumn{5}{|c|}{ Bağımlı Değişken: HACİM } \\
\hline \multicolumn{5}{|c|}{ Örneklem: Ocak 2005-Kasım 2017} \\
\hline Değişken & Katsayı & Std. Hata & t-istatistiği & Sig. \\
\hline SUE & .0145493 & .0013348 & 10.90 & 0.000 \\
\hline TÜFE\% & .0225674 & .0207764 & 1.09 & 0.279 \\
\hline KRİZ & -.5071253 & .0585338 & -8.66 & 0.000 \\
\hline dlKUR & .011801 & .0023718 & 4.98 & 0.000 \\
\hline $\mathrm{C}$ & 11.76432 & \multirow[t]{2}{*}{.3527914} & 33.35 & 0.000 \\
\hline \multicolumn{2}{|c|}{ F istatistiği: 43.57} & & \multicolumn{2}{|l|}{ SS: 12.7842} \\
\hline \multicolumn{3}{|c|}{ Olasılık (F istatistiği): 0.000} & \multicolumn{2}{|l|}{ DF: 154} \\
\hline \multicolumn{3}{|c|}{ R-kare: 0.5374} & \multicolumn{2}{|l|}{ MS: .0830} \\
\hline \multicolumn{3}{|c|}{ Düzeltilmiş R-kare: 0.5251} & & \\
\hline
\end{tabular}

KRİZ değişkeninin katsayısı negatif (-.507) bulunmuştur. Bunun anlamı literatürde de bahsedildiği üzere iki ülke arasında oluşan politik kriz, ülkelerin ticaret hacimlerinde azalmaya neden olmaktadır. $\mathrm{Bu}$ bağlamda, politik risk ülkelerarası ticari ilişkilerin bozulmasına yol açmaktadır hipotezi desteklenmiştir. TÜFE’nin dış ticaret hacmi üzerinde anlamlı bir etkisi bulunmamıştır ${ }^{4}$. Sanayi üretim endeksinin dış ticaret hacmi üzerinde pozitif (.014) yönlü bir etkisi gözlemlenmiştir. Başka bir ifadeyle sanayi üretim endeksi arttıkça, dış ticaret hacmi de artmaktadır. Döviz kurununda hacim üzerinde pozitif (.011) etkisi bulunmuştur. Regresyonun düzeltilmiş $\mathrm{R}^{2}$ değeri \%52,51'dir. Diğer bir ifade ile HACİM değişkenindeki değişsimin \%53'ü regresyon modelinde kullanılan verilerle açıklanabilmektedir.

$\mathrm{Bu}$ çalışmada, Türkiye-Rusya arasında uçak krizi sonrasında gerçekleşen politik riskin oluşması, bu politik riskin sonuçlarının nasıl oluştuğunu yansıtabilmek ve politik riskin iki ülke üzerinde yaratmış olduğu etkileri irdelenmek amacıyla, yukarıda yapılan regresyon analizini destekleyen ve uçağın düşmesi sonrasında ticari ilişkilerin ve uçağın düşürülmeden ilk iki yıl ve uçak düşürüldükten sonra ki iki yıllık yansımalarının nasıl olduğunu inceleyebilmek amacıyla, TÜİK'den alınan raporlar sayısallaştırılmış ve grafikler aracılığıyla açıklanmıştır.

4 Petek ve Çelik (2017, s.69) yapmış olduğu çalışmada "Enflasyon oranlarındaki değişim, kurlardaki, dış ticaret dengesindeki değişim, artış veya azalış bir ülke ekonomisinin makro ekonomik göstergeleri bakımından oldukça önemli bir yer tutmaktadır." şeklinde ifade etmiştir. Yapmış oldukları ekonometrik analizde TÜFE, Döviz kuru, ihracat ve ithalat arasındaki ilişkiyi incelemişlerdir. Yapılan analiz sonucunda TÜFE'nin ithalat üzerinde etkisi bulunmuştur. Hepaktan ve diğ. (2011, s.77) yapmış olduğu çalışmada “Türkiye'de dış ticaret dengesini sağlamak amacıyla gerçekleştirilen bir kur ayarlaması, Türkiye için tek başına kullanılabilecek bir döviz kuru politikası aracı olamamaktadır. Çünkü dıș ticaretin bileșenlerinden ihracat ve ithalatı, döviz kuru politikalarının yanı sıra, birçok unsur etkilemektedir. Bu unsurlar, üretim düzeyi, maliyetler, verimlilik, faiz oranları, sermaye girişi, vergi mekanizması, etkin kaynak kullanımı, enflasyon şeklinde sıralanabilmektedir" şeklinde ifade etmiştir.

TÜFE, TEFE, GSMH, İthalat, ihracat vb. değişkenler temel bazı makroekonomik göstergelerdir. Bu bağlamda dış ticaret göstergesini etkileyen fazla sayıda değişken mevcuttur. Yapılan bu araştırmada, politik krizin dış ticaret hacmi üzerindeki etkisinde kontrol değişkeni olarak ele alınan TÜFE bazlı reel efektif döviz kuru, TÜFE'nin aylık yüzdelik değişimi, Sanayi üretim endeksinin etkileri incelenmiştir. Sonuç olarak, literatürde bahsedilen iktisadi büyüme modellerinde TÜFE değişkeninin modele kontrol değişkeni olarak konulması uygun görülmüştür. Fakat, literatürün aksine bu çalışmada, enflasyonun bir göstergesi olan TÜFE değeri anlamsız çıkmıştır. Gelecek çalışmalarda TÜFE yerine TEFE değeri konulması model için daha uygun olabilir. Çalışmada ulaşılan diğer sonuçlar literatürdeki birçok çalışmada ulaşılan sonuçlar ile aynı yöndedir. 


\subsubsection{Kasım 2015 tarihinde yaşanan politik krizin ithalat-ihracat verilerine} aylık yansıması. Şekil-4'de Türkiye'nin Rusya Federasyonu'na ait olan SU-24 tipi Rus jetini Suriye sınırı yakınlarında 24 Kasım 2015 tarihinde düşürmesi ve sonrasında yaşanan politik krizin ithalat ve ihracat verilerinin aylık yansımasının nasıl olduğunu görebilmemize imkân sağlamaktadır.

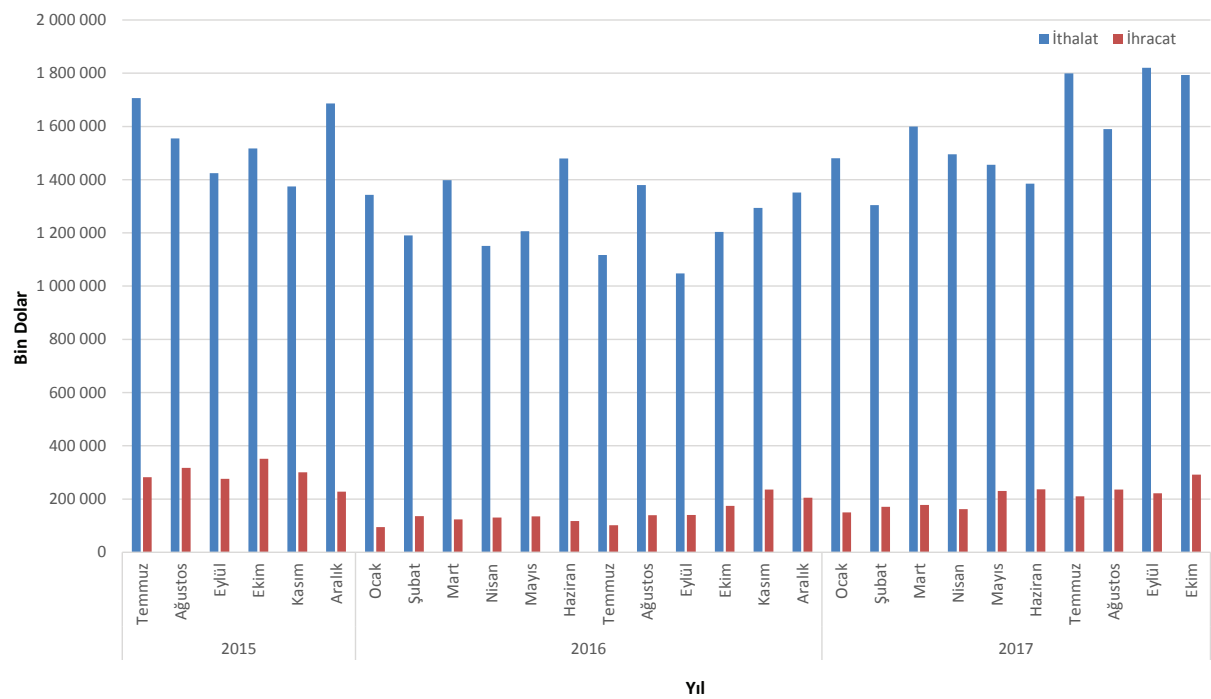

Şekil 4

Uçağın düşürülmesi sonrasında Türkiye ve Rus Federasyonu arasındaki aylık ithalat ve ihracat seyri

Türkiye'nin Rusya Federasyonu'na yapmış olduğu ithalat verilerinin en düşük olduğu aylar uçak düşürüldükten sonraki izleyen aylar ve Rusya Federasyonunun yaptırım uyguladıktan sonraki zaman aralığını yani 2016 yılını kapamaktadır. 2016 yılının ithalat ve ihracat verileri, hem 2015 hem de 2017 yılları arasındaki ithalat ve ihracat verileri ile kıyaslandığında en düşük oranların rastlandığ 1 yılı göstermektedir. 2016 yılı ithalat verileri genel olarak diğer yıllara göre düşüktür ve en düşük verilere sahip olan aylar Şubat (1milyar 190 milyon dolar), Nisan (1 milyar 150 milyon dolar), Temmuz (1 milyar 116 milyon dolar) ve Eylül (1 milyar 47 milyon dolar) aylarıdır. Bu zaman aralıklarında ithalatın daha düşük olmasının sebebi, Rusya Federasyonu'nun Türkiye'den bu zaman aralıklarında daha çok almış olduğu ürünler üzerinde yaptırım uygulaması olabilir.

2016 yılı ihracat verileri, 2015 ve 2017 yıllarına göre ciddi bir düşük yaşamıştır ve en düşük verilere sahip olan aylar Ocak (94 milyon dolar), Mart (123 milyon dolar), Temmuz (101 milyon dolar) aylarıdır. 2015 yılında uçak düşmeden önceki en yüksek ihracat verisi Ekim (351 milyon dolar) ayına aittir ve uçağın düşürüldüğü Kasım (300 milyon dolar) ayın ihracat verisinden sonra Aralık ayında 73 milyon dolarlık düşüşün gerçekleşmesi ile bir kayıp gerçekleşmiştir. 2016 yılının Ocak ayında ihracat oranında çok ciddi bir düşüş ile ihracat kaybı 133 milyon dolar olmuştur. 24 Kasım 2015 yılında uçağın düşürülmesi sonrasında bir yıllık süre Türkiye ve Rusya Federasyonu arasındaki politik krizlerin aşılmasında yeterli olmadığı görülmektedir. 2016 yılı genel olarak ithalat ve ihracat verileri düşük olan bir yıldır. 2017 yılı ithalat ve ihracat verilerine bakıldığında 
2015 y1lının ithalat ve ihracat verilerine ulaşamamış olsa da 2016 yılına göre daha iyi bir tablo sergilemektedir. Özellikle 2017 yılında Mayıs (230 milyon dolar) ayında sonra ihracat verileri artmaya başlamıştır ve uçak krizinden sonra en yüksek ihracat verisi 2017 Ekim (291 milyon dolar) ayında gerçekleşmiştir.

2017 yılında Türkiye'nin Rusya Federasyonundan almış olduğu ürünlerin oranı artış göstermeye başlamıştır. Hatta uçak krizi olayı olmadan önceki veriler dikkate alındığında uçak krizi sonrasındaki en yüksek ithalat verilerine Temmuz (1 milyar 799 milyon dolar), Eylül (1 milyar 820 milyon dolar) ve Ekim (1 milyar 793 milyon dolar) aylarında gerçekleştirilmiştir. Bu sonuçlara göre Türkiye'nin 2017 yılının özellikle son aylarında Rusya Federasyonuna olan bağlılığı arttığı yöndedir. Yukarıdaki grafiğin incelenmesi sonucunda Türkiye'nin ithalat verileri uçak krizi öncesinden çok daha fazla ve en yüksek düzeye ulaşarak Rusya Federasyonuna olan bağımlılığının oranının yüksek olduğunu göstermektedir.

2016 yılında Türkiye'nin Rusya'ya yaptığı ihracatta önemli düşmeler gerçekleşirken ithalatımızda ise daha az bir düşme gözlenmektedir. Bunun en büyük sebebi ise Türk sanayisinin önemli enerji ihtiyacını doğal gazdan sağlanması olabilir. Bu durum Türkiye için risk teşkil etmektedir. Fakat Rusya'nın petrol ve doğal gaz ihracatındaki en büyük müşterisi Avrupa Birliği iken sonrasında Türkiye gelmektedir. Azerbaycan, İran ve Ukrayna gibi ülkeler Türkiye'nin enerji ihtiyacını karşılayabilecek alternatifler arasındadır. Kuzey Afrika'dan bile sıvı doğal gaz ithal edebilme şansı olan Türkiye'nin Rusya'ya karşı çok fazla sıkıntı çekeceği düşünülemez. Bu durumda Rusya'nın da kendisine rakip olabilecek ülkelerinde, Türkiye sayesinde Batı ile ilişkilerini geliştirmesini de hoş karşılamayacağını söyleyebiliriz (Çopuroğlu ve Karpuzcu, 2017). Bu olayı destekler neticesinde, uçak krizinden sonra Gazprom, Türkiye'ye 2016 yılının ilk aylarında yüzde 33,5 daha fazla doğal gaz göndermiştir (Hürriyet, 2016).

\section{Sonuç ve Öneriler}

Yapılan bu çalışmada, Türkiye'nin Rusya Federasyonu'na ait bir uçağı düşürmesi ve bu olayın arından oluşan politik riskin ticari faaliyetler açısından etkisi zaman serisi regresyon analizi ile ve iki yıl öncesi ve iki yıl sonrası değişiklikler grafikler aracılığıyla incelenmiştir. Regresyon analizi ile politik krizin, sanayi üretim endeksinin ve döviz kurunun diş ticaret hacmi üzerinde ilişkisi bulunmaktadır. 24 Kasım 2015 tarihinde yaşanan kriz sonrasında iki ülke arasında gerçekleşen dış ticaret hacmi düşmüştür. Ayrıca, sanayi üretim endeksi ve döviz kurundaki artmalar da dış ticaret hacminde düşmeye neden olmaktadır. Regresyonun modelinin açıklayıcı gücü \%54 bulunmuştur. Bu bağlamda iki ülke arasında politik riskin yaşanması ve yaşanan bu riskin akabinde bu olayın ticari faaliyetlere nasıl yansıdığını gösteren akademik bir araştırmanın yapılmamış olması bu çalışmanın ele alınmasını sağlamıştır. Politik krizler istenen bir durum değildir, fakat politik krizler ekonomik ve sosyal ilişkilerin düzeyinde değişikliğin oluşmasına sebep olmaktadır. Çalışma sonucunda elde edilen bilgiler doğrultusunda politik krizlerin; ithalat ve ihracat verilerine etkide bulunduğu ve bu etki krizin şiddetine, ülkeler arası iletişimin şekline, tekrardan iş faaliyetlerinde bulunma sürecine etkide bulunduğu yöndedir.

Bu güne kadar yapılan bilimsel yayınlar, Türkiye ve Rusya arasındaki ilişkileri daha çok ekonomik ilişkiler ve politik ilişkiler açısından incelemiştir. Türkiye-Rusya arasındaki ekonomik ilişkilerin politik olaylar karşısında çok hassas olduğu ticari faaliyetlerdeki 
iniş ve çıkışların yoğunluğundan anlaşılabilir. İki ülke arasındaki siyasi dengesizliğin giderilmesi ekonomik ve ticari ilişkilerin düzene girmesine katkıda bulunacaktır. Politik kriz ya da herhangi bir kriz oluştuktan sonra önemli olan krizin nasıl yönetildiğidir. Krizi yönetebilmek uygulanan stratejinin varlığının göstergesidir. Bu durum krizden çıkmak için nasıl bir yol izlendiği ve hangi stratejilerin uygulandığını vurgulamaktadır. Türkiye ve Rusya arasındaki ilişkilerin belirli bir düzende ilerlemesi en azından her iki ülkenin doğrudan çatışmaması Türkiye ve Rusya Federasyonu'nun gelecek dönemlerdeki ilişkilerinde büyüme trendi açısından ve gelecek dönemlerde uygulayacağı stratejileri belirli bir istikrarda ilerlemesini sağlayabilir. Türkiye'nin uçak krizi olayından sonra uygulamış olduğu stratejilerinin çokta başarılı olmadığı ithalat ve ihracat sonuçlarına yansımıştır denilebilir. Çünkü Türkiye'nin Rusya Federasyonuna yaptığı ihracat verileri hala 2014 yılı verilerine ulaşamamıştır.

Politik krizlerden uluslararası şirketlerin daha az zarar görmesinin ve çevrelerine daha iyi uyum sağlayabilmeleri için Peng (2009) Global Strategy kitabında, Joint Venture ortaklık sistemlerinin avantajlarının maliyeti paylaşmak ve ortağın bilgi ve varlıklarından yararlanmanın dışında politik olarak kabul edilebilir olduklarından bahsetmiştir. Ayrıca Peng, Greenfield yatırımların politik problemler ve risklerle karşılaşmasının muhtemel olduğunu vurgulamıştır. Yani, lisans yoluyla yapılan ortaklıklar veya Joint Venture ortaklık yapıları, Greenfield yatırımlara ve doğrudan yabancı yatırımlara göre politik krizlerden daha az etkileneceklerdir (Peng, 2009). Politik risklerin çok fazla olduğu ülkelere yatırım yapmayı planlayan çok uluslu şirketlerin ortaklık yoluyla bu ülkelerde yaşanan krizlerden daha az etkileneceklerdir. Türkiye Rusya Federasyonu ve diğer ülkelerle yapmış olduğu ithalat ve ihracat faaliyetlerini Peng'in (2009) bahsettiği yöntemlerle uygularsa bir nebze de olsa karşılaşmış olduğu krizleri daha az hasar ile atlatabilir.

Sonuç özetlenirse, iki ülke arasında yaşanabilecek politik krizler ülkelerin ticari faaliyetlerini olumsuz yönde etkilemektedir. Uluslararası firmalar bunların bilincinde olarak, riskin fazla olduğu ülkelerde doğrudan yatırımlar yerine, ortaklık şeklinde ilerlemelidirler. Rusya ve Türkiye arasında 24 Kasım 2015 tarihinde yaşanan Uçak krizi iki ülke açısından politik krize dönüşmüş ve ticarette ciddi kayıplar verilmesine neden olmuştur. Yapılan bu çalışmada kullanılan değişkenlerden sanayi üretim endeksi verilerinin 2005 yılında başlaması, modeli zaman açısından sınırlamıştır. Gelecek çalışmalar da başka değişkenler kullanılarak zamanın daha geniş tutulması veya sektörel mukayeselere yer verilmesi Türkiye ve Rusya arasındaki krizleri daha iyi açıklayabilecektir. Ayrıca, politik krizlerin izlerini sadece Türkiye-Rusya örneği üzerinden değil de başka ülkelerle yaşanan krizler üzerinden de göstermek mümkün olacaktır.

\section{Kaynakça}

Akbulut, G., Yılmaz, C. (2015). “Türkiye-Rusya Dış Ticaretinin Sektörel Düzeyde Analizi”, Internatıonal Conference on Eurasian Economies, (pp. 431-436).

Asche, F., Osmundsen, P., Tveteras, R. (2002). “European Market Integration for Gas? Volume Flexibility and Political Risk” Energy Economics, 24, 249-265.

Babal1, T. (2012). "The Role of Energy in Turkey's Relations with Russia and Iran" Center for Strategic and International Studies, Ankara.

BBC (2016b,01.01), Kremlin: Erdoğan Özür Diledi. Retrieved from http://www.bbc.com/turkce/ haberler/2016/06/160624_erdogan_rusya, 15.10.2017.

BBC. (2016a, 05 31). Erdoğan: Rus Uçă̆ı Olduğunu Bilseydik Farklı Davranırdık. Retrieved from www.bbc. com/turkce, 16.10 .2017$. 
Bilgin, T., Çelik, C. (2016). The Evaluatıon Of The Effect Of The Aircraft Crisis on Turkush Economy with Foreign Trade Data. Sirene Belek Hotel, Antalya, Turkey, 14(16), 101.

Bourgeot, R. (2013). Russia-Turkey: A Relationship Shaped by Energy. Russie. NEI. Visions, (69).

Bunn, D., W., Mustafaoglu, M. M. (1978). Forecasting Political Risk. Management Science, 24, 1557-1567.

Çopuroğlu, Ö., Karpuzcu, T. (2017). Krizlerin Yön Verdiği Türk - Rus İlişkilerine Uçak Krizine Kadar Analitik Bir Bakış: 2004 - 2016. Süleyman Demirel Üniversitesi, 22(2), 465-483.

Danıell, M. (2000). World of risk. Singapore: John Wiley. Dictionary.com. (2017, 12 7). Retrieved from http:// www.dictionary.com

Demir, A. O., Çınar, A. (2016). Politik İstikrarsızlığın Ekonomik Etkileri: 24 Kasım Sonrasında Türkiye-Rusya Ekonomik İlişkileri. Istanbul Ticaret Üniversitesi Sosyal Bilimler Dergisi, 311.

Demir, E. (2015). Rusya'nın Yaptırımlarının Türkiye Ekonomisine Olası Etkileri. Bilgi Notu, Türkiye İş Bankası, İktisadi Araştırmalar Bölümü, İstanbul.

Fitzpatrick, M. (1983). The Definition and Assessment of Ppolitical Risk in International Business: A Review of the Literature. Academy of Management Review, 8(2), 249-254.

Hepaktan, C. E., Çinar, S., Dündar, Ö. (2011). Türkiye'de Uygulanan Döviz Kuru Sistemlerinin Dış Ticaret Ille İlişkisi. Akademik Araştırmalar ve Çalışmalar Dergisi, (Akad), 3(5).

Hill, C. (2002). International Business: Competing in the Global Marketplace. London: McGraw-Hill.

Hillman, A., Wan, W. (2005). The Determinants of MNE Subsidiaries'Political Strategies. JIBS, 36, 322-340.

Hornby, A. S., Cow1e, A. P., Lew1s, J. W. (1974). Oxford Advanced Learner's Dictionary of Current English (Vol. 4). London: Oxford University Press.

Hürriyet. (2016, 05 22). Rusya Türkiye’ye Verdiği Gazı Arttırdı. Retrieved from http://www.hurriyet.com.tr/ rusya-turkiyeye-verdigi-gazi-artirdi-40070489, 18.10.2017

Jazeera, A. (2016, 12 31). Putin Dönemi Türk-Rus İlişkileri. Retrieved from http://www.aljazeera.com.tr/aljazeera-ozel/putin-donemi-turk-rus-iliskileri, 20.10.2017

Kantar, G. (2016). Türk Siyasetinde Politik Dil Kullanımı: Recep Tayyip Erdoğan'ın 3 Kasım 2002 Genel Seçimleri Miting Konuşmalarının, Söylem Dilinin İçerik Analizi, Sosyal Bilimler Metinleri, Aralık Icomep Özel Sayıs1, 670-692.

Kesimli, İ., G. (2011). Turizm Perspektifinden Politik Krizlerin Ekonomiye Yansimalarl, Electronic Journal Of Vocational Colleges, 1(1).

Kobrın, S. J. (1982). Managing Political Risk Assessment. California: University of California.

Miller, K., D. (1992). A Framework for Integrated Risk Management in International Business. Journal of International Business Studies, 23(2), 311-331.

Oxelheım, L., Wihlborg C. (1987). Macroeconomic Uncertainty: International Risks and Opportunities for the Corporation: New York: John Wiley and Sons.

Özbay, F. (2011). Soğuk Savaş Sonrası Türkiye-Rusya İlişkileri:1992-2010.Bilge Strateji, 3(4).

Özlük, E. (2015). 'Türkiye ve Rusya Arasındaki Uçak Krizi ve Özür Meselesi”, ORSAM Bölgesel Gelişmeler Değerlendirmesi,35, 1-12.

Petek, A., Çelik, A. (2017). Türkiye'de Enflasyon, Döviz Kuru, İhracat ve İthalat Arasındaki İlişkinin Ekonometrik Analizi (1990-2015)/An Econometric Analysis of The Relationship between Inflation, Exchange Rate, Export and Import in Turkey (1990-2015). Finans Politik \& Ekonomik Yorumlar, 54(626), 69.

Peng, M. (2009). Global Strategy (2 ed.). OH: South Western, Cengage Learning.

Savaş, İ., Can, İ. (2011). Euro-Dolar Paritesi ve Reel Döviz Kuru'nun IMKB 100 Endeksi'ne Etkisi. Eskişehir Osmangazi Üniversitesi İIBB Dergisi, 6(1), 323-339.

Shubık, M. (1983). Political Risk: Analysis, Process, and Purpose. New York: Cambridge University Press.

Simon, J. (1982). Political Risk Assessment: Past Trends and Future Prospects. Columbia Journal of World Business(Fall), 67-71.

Simon, J. (1984). A Theoretical Perspective on Political Risk. Journal of International Business Studies, 15(3), 123-143.

Ting, W. (1988). Multinational Risk Assessment and Management. Westport, Conn.: Greenwood Press.

Truitt, F., J. (1974). Expropriation of private investment. Indiana: Division of Research, Graduate School of Business, Indiana University.

Türkiye Cumhuriyeti Dışişleri Bakanlığı (2016 05 22), Türkiye-Rusya Ekonomik ve Ticari Ilişskileri. Retrieved from http://moskova.be.mfa.gov.tr/ShowInfoNotes.aspx?ID=219659, 28.11.2017

Tüz, M., V. (1996). Kriz Döneminde İşetme Yönetimi. Bursa: Ekin Kitapevi Yayınları.

Yenişehirlioğlu, E., Salha, H., Şahin, S. (2016). Politik Krizlerin Turizm Talebi Üzerindeki Etkisine Yönelik Bir Araştırma: Rusyanın Değişen Yüzü ve Bu Değişimin Türkiye Turizmine Etkileri.

Zete (2015 05 31), Türkiye'nin, Uçağın Rus Jeti Olduğunu Bilmemesi Mümkün Değil Retrieved from https:// zete.com/turkiyenin-ucagin-rus-jeti-oldugunu-bilmemesi-mumkun-degil/, 28.11.2017 